\title{
電力系統の静的状態推定における並列計算 アルゴリズムについての一研究
}

\author{
正員佐々木 博司 (広島大)
}

\section{1. 緒言}

電力系統への状龍推定理論の適用は，系統のオンラ イン状態監視のための高精度はデータベース作成の最 も有力な手法であり，既に実用化されている(1)。状態 推定とは冗長な観測值をもとにある規範を最小化する 状態变数值を求めるソフトゥェアであり，ハードウェ 了(測定装置)の精度を補強する機能がある。

電力系統の状態变数は通常“ノード電圧の大きさ之 位相角”であり，一方観測值はノード注入電力, 線路 潮流，ノード電圧であるので，観測方程式は状態变数 の非線形関数となり，大次元の連立一次方程式友復 して解く問題洲着する(2)。

大規模な電力系統にオンラインで啇用するには状態 推定計算高速価実行する必要があり，標準的な重み 付き最小二乗法加出発して圧々の效率的アルゴリズ ムが検討されてきているが(3)(4)，乙の方向での効率化 はほぼ限界优づいていると考无られる。

一方，ILLIAV IV に始まるマルチプロセッサまた はアレイプロセッサ在利用する並列計算アルゴリズム が各分野で活発化研究され，電力系統の分野古例外で はない(5) (7)。更江, 最近の LSI 技術の進展汇伴い，

高速の 32 ビットマイクロコンピュータも近々市場化 されようとしており，安洒なマイクロプロセッサを利 用して使用目的に合致したマルチプロセッサシステム を自由自在に組み上げることのできる日もをれはど遠 くないであろう。

ところで，電力澈流計算や状態推定計算のように， 極度にスパース性の強い方程式に対し，CRAY-Iなど のスーパコンピュータまたはアレイプロセッサを適 用してあ予想したほどの速度向上比が得ら机ていない

A Study on a Parallel Computation Algorithm in The Static State Estimation of an Electric Power System. By Hiroshi Sasaki, Member (Department of Electrical Engineering, University of Hiroshima).

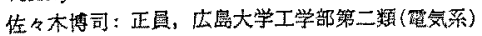

昭 $57-12$
のが実状である(8)。この種の計算に対しては，䉓力䒺 紶のノードごとあるいは，数ノードごとにプロセッサ を割り付ける MIMD (Multiple-Instruction stream Multiple-Data system) 形の並列計算機がより適して いると考无られる。

本研究に扔いては，MIMD 珍計算機に適した計算 アルゴリズムとして，点ヤコビ法を基本とする万法を 提案し(9)，その収束特性を左右する主要因と考えられ る。

(1) 係数行列の特性

(2) 観測值データの選定法

(3) 最適加速保数

(4) 電力䒺統のサイズ

（5）並列計算モデルの精密化

の諸項目について理諭的考察ならびに実規模柔統への 適用例基㰸討する。

一般に LU 分解に基つくく直接解法は直列 (Serial) 計 算アルゴリズムの中で最む強力であり, 系統のサイズ 飞依存せず 4〜5 回の反復で収束する。一方，点ヤコ ビ法沈反復回数は多くなるが，ノードの順序付けおよ び係数行列の LU 分解 (通常最む計算時間を要す) が 不要であることならごに計算の並列度が非常に高い ，という利点を有するのでそのの有効性についての究明 は洒値あることと思われる。

なお，状態推定においては，不良デー夕检出をざの ように行なうかが大きな問題であるが，筆者は既に時 系列を利用した，不良データ検出法を先保提案してい る(10)。乙の検出方法は，並列計算アルゴリズム向きの 万法であって，的確に不良デー夕の検出ができる。従 って本研究に批いては，不良データの混入についての 検討は行なっていない。

\section{2. 状態推定問題の定式化}

電力系統の最良の状態量を推定するために選ばれ 石観測值は，ノード注入電力 $\left(P_{i}, Q_{i}\right)$, 線路潮流 


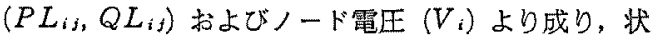
態量の非線形関数と観測雑音の和として与えられる。 いま $N$ ノード系統を考元，観湘值数を $m$ 個とすれ ば，勧測值ベクトル $\boldsymbol{Z}_{M}$ は $n=2 \cdot N^{*}$ 次元の状態量 ベクトル $\boldsymbol{x}$ により次式で表わされる。

$$
\begin{aligned}
& \boldsymbol{Z}_{M}=\boldsymbol{f}(\boldsymbol{x})+\boldsymbol{v} \\
& \boldsymbol{x}^{T}=\left(\delta_{1}, V_{1}, \delta_{2}, V_{2}, \cdots, \delta_{N}, V_{N}\right)
\end{aligned}
$$

但し, $\delta_{i}$ は第 $i$ ノドの笔王位相角, $\boldsymbol{v}$ は次元観測雑 音べクトルであり，次の性㙺をもつと仮定する。

$$
E\{\boldsymbol{v}\}=\mathbf{0}, \quad E\left\{\boldsymbol{v} \cdot \boldsymbol{v}^{T}\right\}=R=\operatorname{diag}\left\{r_{1}, r_{2}, \cdots, r_{m}\right\}
$$

こに, $E\{\}$ は期待值操作を, 肩字 $T$ は行列と心゙ クトルの祘置を意味する。

電力系統の静的状態推定計算は, 重み付き評価式

$$
J(\boldsymbol{x})=\left[\boldsymbol{Z}_{M}-\boldsymbol{f}(\boldsymbol{x})\right]^{T} R^{-1}\left[\boldsymbol{Z}_{M}-\boldsymbol{f}(\boldsymbol{x})\right]
$$

を最小化する $x$ の値 $\hat{x}$ を求ぬる問題に帰着する。 よって，x の最良推定値 $\hat{x}$ は次式の解として得られ る。

$$
\frac{\partial J(x)}{\partial \boldsymbol{x}}=-2 H^{T}(\boldsymbol{x}) R^{-1}\left[\boldsymbol{Z}_{M}-\boldsymbol{f}(\boldsymbol{x})\right]=0
$$

とこで, $H(x)=\partial f(x) / \partial x$ であり， $H(x)$ を構成する $m \times 1$ ベクトル $\boldsymbol{h}_{i}(i=1 \sim n)$ および $1 \times n$ 行ベクト ル $\boldsymbol{g}_{i}(i=1 \sim m)$ をそれぞれヤコビアン列ベクトルお よび行べクトルと呼かととにする。

さて，(4)式を Newton-Raphson (N-R) 法で解く ためには， $J(\boldsymbol{x})$ の Hessian 行列の $1 / 2$ を $\boldsymbol{\Gamma}(\boldsymbol{x})$ 上 おくとき

$$
\begin{aligned}
& \Gamma\left(\boldsymbol{x}^{K}\right)\left(\boldsymbol{x}^{K+1}-\boldsymbol{x}^{K}\right) \\
& \quad=H^{T}\left(\boldsymbol{x}^{K}\right) R^{-1}\left(\boldsymbol{Z}_{M}-\boldsymbol{f}\left(\boldsymbol{x}^{K}\right)\right]
\end{aligned}
$$

を反復して解けばよい(1)。但し，

$$
\left.\begin{array}{l}
\Gamma(\boldsymbol{x})=H^{T}(\boldsymbol{x}) R^{-1} H(\boldsymbol{x})-B(\boldsymbol{x}) \\
B(\boldsymbol{x})=\sum_{i=1}^{m} G_{i}(\boldsymbol{x})\left[\boldsymbol{Z}_{M i}-f_{i}(\boldsymbol{x})\right] \frac{1}{r_{i}}
\end{array}\right\} \cdots(
$$

であって, $G_{i}(\boldsymbol{x})$ は $f_{i}(\boldsymbol{x})$ ○ Hessian 行列である。 $\Gamma(\boldsymbol{x})$ 中の $B(\boldsymbol{x})$ が無視できるとき(微小残差問題)，

(5)式は

$$
\begin{gathered}
H^{T}\left(\boldsymbol{x}^{K}\right) \cdot R^{-1} H\left(\boldsymbol{x}^{K}\right)\left(\boldsymbol{x}^{K+1}-\boldsymbol{x}^{K}\right) \\
=H^{T}\left(\boldsymbol{x}^{K}\right) R^{-1}\left[\boldsymbol{Z}_{M}-\boldsymbol{f}\left(\boldsymbol{x}^{K}\right)\right]
\end{gathered}
$$

となり，最小二乗問題における正規方程式に帰着す る。

ここで， $\Delta x^{K} \triangleq x^{K+1}-x^{K}$ と抽て，(5)式あるい は（7）式を一般的汇次のように表現する。

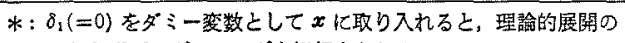
みならずプログシミング上好都合となる。

$$
A\left(\boldsymbol{x}^{K}\right) \Delta \boldsymbol{x}^{K}=\boldsymbol{b}\left(\boldsymbol{x}^{K}\right)
$$

係数行列 $A(\boldsymbol{x})$ は(6)式，また右辺ベクトルb(x)は $\partial J(x) / \partial x$ であり $\Delta x^{K \rightarrow 0(k \rightarrow \infty)}$ となったとき， 自動的に(4)式が解けたことになる。

\section{3. 点ヤコビ法に基づく並列計算アルゴリズ} 厶

〈3.1〉 点ヤコビ法の定式化 ${ }^{(12)} \hat{x}$ を求めるため の(8) 式は通常の線形方程式之は異なり, 係数行列 $A$ 之右辺ベクトルb は $\boldsymbol{x}$ の関数でありステップ $K$ が 進むにつれ変化するが，Kを固定して考えれば線形方 程式に変わりはない。

LU 分解迀直接解法を用いれば，(8)式は唯一 度の前進怙よび後退代入で解くことができるが，粕言 であ述へたように，ての方法は高度に直列的で並列計 算に不向きである。従って, 計算上の並列度の最む高 い点ヤコビ法に基づく解法を検討する。

(8)式に拈いて，屑字 $K$ はある值に固定されてい ると考えて省略し， $\boldsymbol{y}=\Delta x$ とおいて書き直すと，

$$
A \boldsymbol{y}=\boldsymbol{b} \text {. }
$$

更に，A を次のように分離する。

$$
A=D-F
$$

但し， $D$ は $D \triangleq \operatorname{diag}\left\{A_{11}, A_{22}, \cdots, A_{N N}\right\}$ なるブロッ ク対角行列, $A_{i i}$ は次のような $2 \times 2$ 主小行列式であ る。

$$
A_{i i}=\left[\begin{array}{cc}
a_{p p} & a_{p, p+1} \\
a_{p+1, p} & a_{p+1, p+1}
\end{array}\right] \quad p=2 \cdot i-1
$$

(10)式の分離を利用して，(9)式を点ヤコビ法*で 解いた䋠助的な反復ベクトル $\tilde{\boldsymbol{y}}^{(l+1)}$ は

$$
\tilde{\boldsymbol{y}}^{(l+1)}=D^{-1} F \boldsymbol{y}^{(l)}+D^{-1} \boldsymbol{b} .
$$

上って，適当な加速係数 $0<\alpha<\alpha_{m}$ を用いて

$$
\begin{aligned}
\boldsymbol{y}^{(l+1)} & =\boldsymbol{y}^{(l)}+(1+\alpha)\left\{\tilde{\boldsymbol{y}}^{(l+1)}-\boldsymbol{y}^{(l)}\right\} \\
& =M_{\alpha}{ }^{k} \boldsymbol{y}^{(l)}+\boldsymbol{C} \ldots \ldots \ldots \ldots \ldots \ldots \ldots \ldots \ldots \ldots \ldots \ldots
\end{aligned}
$$

但し,

$$
\left.\begin{array}{l}
M_{\alpha}{ }^{K} \triangleq-\alpha I+(1+\alpha) D^{-1} F \\
\boldsymbol{C} \triangleq(1+\alpha) D^{-1} \boldsymbol{b}
\end{array}\right\}
$$

(11)，(12)式汇拈いて，(8)式の $K$ と区別するため， (9)式を解くための反復回数は $(l)$ としている。

(12)式は収束を早めるために，加速係数学入した 点ヤコビ法である。加速係数の上限值 $\alpha_{m}$ は(13)式の ヤコビ行列 $M_{d}{ }^{K}$ のスペクトル半经が 1 以下, 即方

$$
\rho\left(M_{\alpha}{ }^{K}\right)<1
$$

で抑えられる。従来通りに，(7)式の正規方程式を解

*: (11)式はノート電压上立相角の 2 变数を同時代修正するので， 骤密には点ヤコビ法の名称は正しくないが, 各ノードの2 変数 をひとまとめと考えるとととし，ての名称を用いている。 
くとす㣗は，係数行列 $A$ は正規行列の特性加ら正定 值行列となる(13)。乙のとき， $0<\alpha<\alpha_{m}<1$ なる $\alpha$ の 值に対し， $M \alpha^{K}$ 㹥(14)式の条件满足し，収束行列 となることが証明できる(付録参照)。

〈3.2〉並列計算アルゴリズム本研究で提案す る並列計算アルゴリズムは， $x^{K}$ を固定して (12)式が ある程度収束した段階で, $\boldsymbol{x}^{K}+\boldsymbol{y} \rightarrow \boldsymbol{x}^{K}$ として $\boldsymbol{A}\left(\boldsymbol{x}^{K}\right)$ ， $\boldsymbol{b}\left(\boldsymbol{x}^{K}\right)$ を更新し，再び(12)式を解くという手順促 うもので以下のようにまとめられる。

(i) 初期推定值を $x^{0}$ とする。

(ii) $x^{K}(K \geq 0)$ を用いて $A\left(x^{K}\right)$ を計算する。

(iii) $x^{\mathrm{K}}(K \geq 0)$ を用いて $\boldsymbol{b}\left(x^{K}\right)$ を計算する。

(iv) (12)式を反復して解き， $\left\|\Delta \boldsymbol{y}^{(l)}\right\|<\varepsilon_{l}$ となる かまたは反復回数 $l=l_{\max }$ になったとき次のステップ へ行く。但し, $\Delta \boldsymbol{y}^{(l)}=\boldsymbol{y}^{(l+1)}-\boldsymbol{y}^{(l)}$

(v) $\Delta x^{k}=\boldsymbol{y}^{(l+1)}$ とし, $\left\|\Delta x^{K}\right\|<\varepsilon_{K}$ ならばステ ップทî, その他のときは次へ。

(vi) $x^{K+1}=x^{K}+\Delta x^{K}, K+1 \rightarrow K$ とし, $\operatorname{MOD}(K$, $K_{\mathrm{up}}=0$ ならばステップ ïへ。非零のときはステップ iiin行く。

（vi） $\hat{x}=x^{K}+\Delta x^{K}$ を最良推定值として計算を終 了する。

上述のアルゴリズムにおいて注意すべき点は，(12) 式の解が得られ，K方増加するごとに右辺ベクトル $\boldsymbol{b}$ $\left(\boldsymbol{x}^{K}\right)$ を再計算するが，係数行列は $K_{\mathrm{up}}$ 回どとにしか 更新しない点である。

何故ならば, $\boldsymbol{b}$ は定義関数 (Defining function) で あるから，常に更新計算する必要があるが，Aの変化 は比較的䌅やかであるので，計算効率の点加らみても $K$ K増加するごとに再計算することは得策でない。そ して，並列計算の行なわれるのは $\square$ で囲んだステ ップ(ii)〜 (iv)であるが，その方法について以下に検 討する。

4. マルチプロセッサシステムによる並列計 算アルゴリズムの実現

本節に和いては各ノードに1個のプロセッサを割り 当てる方式を想定し，前節のアルゴリズムの計算上の 並列度をできるだけ高める方策を検討する。このため には，ステップ（ï）（iv)加ら明らかなように, $A, \boldsymbol{b}$ の計算法之(12) 式の解法を並列計算法に適合するよう に工夫する必要がある。その準嗝として，Aとbの ヤコビアン行べクトルによる定義,および(12)式の $N$ 個の式化上る分割表示を与える。

$\langle 4 \cdot 1\rangle$

$\boldsymbol{A}, \boldsymbol{b}$ のヤコビアン行ヘクトルによる定義
$A$ 扰よび b の定義は (5)〜 (7)式から明らかなよ うに，ヤコビアン列ベクトル $\boldsymbol{h}$ によるのが自然であ るが，これは並列計算アルゴリズムに不適なだけでな く, SISD 形計算機による従来のアルゴリズムに適用 したとしてむ極わめて非能率となる。

との欠点は， $A$ とb をヤコビアン行べクトル $\boldsymbol{g}$ で 定義するととにより回避できる(6)式と(5)式より 若干の計算過程を経て次式が得られる。

$$
\begin{aligned}
& A=\sum_{i=1}^{m}\left[\frac{1}{r_{i}} \boldsymbol{g}_{i}{ }^{T} \boldsymbol{g}_{i}-\frac{\partial \boldsymbol{g}_{i}{ }^{T}}{\partial \boldsymbol{x}} \Delta \boldsymbol{Z}_{i}\right] \ldots \\
& \boldsymbol{b}=\sum_{i=1}^{m} \boldsymbol{g}_{i}{ }^{T} \Delta \boldsymbol{Z}_{i} \ldots \ldots \ldots \ldots \ldots \ldots \ldots \ldots \ldots \ldots \ldots \ldots
\end{aligned}
$$

但し，

$$
\begin{aligned}
& \Delta \boldsymbol{Z}_{i}=\frac{1}{r_{i}}\left[\boldsymbol{Z}_{M i}-f_{i}(\boldsymbol{x})\right] \\
& \boldsymbol{g}_{i} \triangleq \frac{\partial f_{i}(\boldsymbol{x})}{\partial \boldsymbol{x}} \triangleq \nabla f_{i}(\boldsymbol{x})
\end{aligned}
$$

ここで, $\boldsymbol{g}_{i}$ は第 $i$ 観測值 $Z_{M}$ に対応する観測計算式 $f_{1}(x)$ のこう配ベクトルであることは明らかである う。上述の定義式を用いるととにより，従来の逐次形 計算アルゴリズムにおいてもヤコビアン行列 $H$ を完 全に作成する必要はなく，全観測值を逐次的行処理し ていけば, $A$ 上bは自動的に計算されてくる。

一方, 本研究で提案する並列計算アルゴリズムにお いても， $g_{i}$ による $A$ とbの定義は各プロセッサが， $A, \boldsymbol{b}$ の計算のために必要とするデータの局所性を明 確に把握でき，㖕算上の並列度の見積りおよびマルチ プロセッサのアーキテクチャの基碟となる。

〈4・2〉 マルチプロセッサによる並列解法 先に 述べたように，本研究では $N$ 個のプロセッサによる 並列計算アルゴリズムについて議論しているので(12) 式を $N$ 個の式に分割表示する必要がある。

まず，(2)式の $x$ を次のように再定義する。

$$
\boldsymbol{x}^{T}=\left(\boldsymbol{X}_{1}{ }^{T}, \boldsymbol{X}_{2}{ }^{T}, \cdots, \boldsymbol{X}_{N^{T}}\right) ; \boldsymbol{X}_{i}{ }^{T}=\left(\delta_{i}, V_{i}\right)
$$

ここで， $\boldsymbol{X}_{i}$ をノード $i$ の状態変数と呼ぶ。. $1 \leqq i, j \leqq$ $N$ なる $i, j(i \neq j)$ に対し, $p=2 i-1, q=2 j-1$ と すると

$$
A_{i j}=\left[\begin{array}{cc}
a_{p, q} & a_{p, q+1} \\
a_{p+1, q} & a_{p+1, q+1}
\end{array}\right]=A_{j i}{ }^{T}
$$

なる $2 \times 2$ 行列は， $\boldsymbol{X}_{\boldsymbol{i}}$ と $\boldsymbol{X}_{\boldsymbol{l}}$ 亿対応する $A$ の部分行 列であり（10)式の分離に戈いては $F$ に含有される。

(19)式で定義した $\boldsymbol{X}_{i}$ に対応して， $\boldsymbol{Y}_{i} \triangleq \Delta \boldsymbol{X}_{\boldsymbol{i}}$ とお くと，(12)式は $N$ 本の式に分割表示できる。

$$
\boldsymbol{Y}_{i}^{(l+1)}=-\alpha \boldsymbol{Y}_{i}^{(l)}+(1+\alpha) A_{i i^{-1}}
$$




$$
\begin{array}{r}
\times \sum_{j \neq i}^{N} A_{i j} \boldsymbol{Y}_{j}^{(l)}+(1+\alpha) A_{i i}^{-1} \boldsymbol{b}_{i} \\
i=1 \sim N \ldots \ldots(21)
\end{array}
$$

但し,

$$
\boldsymbol{b}_{i}{ }^{T}=\left(b_{p}, b_{p+1}\right), \quad p=2 \cdot 1-1
$$

(21)式は次のように解釉できる。すなわち，第 $i$ 人 一ドに割り付けられたプロセッサは，Kが更新される ごとに $\boldsymbol{b}_{i}$ を，Kup 回ごとに $A_{i j}(j=1 \sim N)$ を再計 算した後 (20) 式の反復解法に移るが，2 回目以降の反 復においては $A_{i j} \neq 0$ なる $j$ に対し， $A_{i j} \boldsymbol{Y}_{j}{ }^{(l)}$ の計 算に籍 $j 7^{\circ}$ ロ七ッサの計算結果 $\boldsymbol{Y},(t)$ を参照する必 要がある。

係数行列 $A$ のスパース性加ら $A_{i j}(j \neq i)$ のほ之ん どは零行列上考えて良いが，どの $A_{i j}$ が非雾となる 加は $A$ のトポロジー特性*加ら定まる。著者は既に， Aのトポロジーは, 系統のトポロジー情報(接続状態 を示す $N$ ノード無向グラフ $\left.G_{C}{ }^{* *}\right)$ と，観測值情報 をトポロジー情報へ等価变換したものと加ら決定され ることを明らがした ${ }^{(14)}$ 。さて，Aij 中の4要素は 同時に零または非零となるのだ，Aのトロポジ一を研 究するには $A_{i j}$ をスカラーに退化させた $N \times N$ 行列 で十分である(14)。民こで， $N \times N \bigcirc 2$ 值行列 $B=$ $\left\{B_{i j}\right\} \rightleftarrows$

$$
\begin{aligned}
& B_{i j}=1 \quad i=1 \sim N \\
& B_{i j}=\left\{\begin{array}{ll}
1 & \text { if } A_{i j} \neq 0 \\
0 & \text { if } \quad A_{i j}=0
\end{array} \quad(i, j=1 \sim N)\right.
\end{aligned}
$$

なる規則で $A$ 加ら作成する。そして，i，jをノード に対応させ， $B_{i j}=1$ となるノード対 $i$ と $j$ を枝で結 んでいくと，Aのトポロジーを表現するNノードの 無向グラフ $G_{B}$ を得る。

一般に， $G_{B}$ 注 $G_{C}$ にない枝を含むが，乙れはノ一 ド注入電力歓測檤によるもので，てれを图10例で説 明する。図は部分系統の接続図（グラフ $G_{C}$ ) に観測 值情報を書き込んだすのであるが，ノード $j$ とに 㧊いて注入電力を観测している。その結果, 図 $20 A$ のトポロジー特性を表わすグラフ $G_{B}$ に戈いては，点 線で示した新しい枝が付加されて，ノード $j$ 己 $m$ の $G_{C}$ 亿和ける，隣接ノードは完全に相互結合されてい る。GC に存在していた枝 $(i-l)$ 加 $G_{B}$ に执いては

*: $M=\left\{M_{i j}\right\}$ を $p \times p$ 効称行列とするとき， $p$ ードの然向グラ フを考元，行(列)番号を一个番号汇対応させ， $M_{i j} \neq 0(i \neq j)$

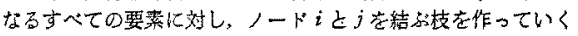
とき，乙の無向グラフ结行列 $M$ の非露要慗の出琪パターンの

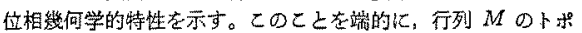
口゙ー特性と呼离。

“**: 電力系統の母線をノードに，線路を枝にそれぞれ 1 対 1 対应さ

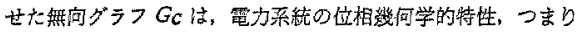

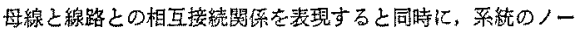
トアドミタンス行列のトポロジー特性も示す。

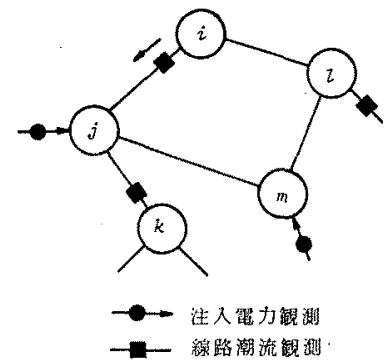

図 1 電力承統接続図(グラフ $G_{C}$ ) および観测值 情報の指定

Fig. 1. The connection diagram of an electric power system (Graph $G_{c}$ ) and specification on the measurement set.

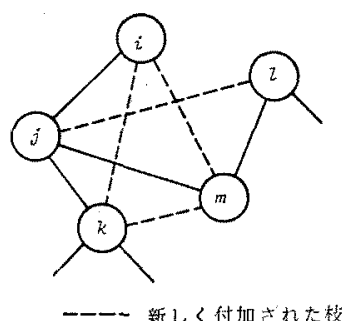

図 2 係数行列 $A$ のトポロジー特性を示すが ラフ $G_{B}$

Fig. 2. Graph $G_{B}$ repesentinting the topological property of the coefficient matrix $A$.

取り除かれているが，乙れは線路 $(i-l)$ の潮流が観測 されておらず，また両端ノード $i$ としでの注入電力す 観測していないからである。しかしながら，注入電力 を適当に含むように，観測值セットを選定した場合， $G_{C}$ 加ら除去される枝は $G_{B}$ に付加される枝に比較し てはるかに少ない。

系統のトポロジー情報と観測值情報と加ら，係数行 列 $A$ のトポロジーを示高無向グラフ $G_{B}$ が得られる と, 各プロセッサが(21)式を反復して解く上で必要な 情報を確保できる。

\section{5. 並列計算アルゴリズムの収束性}

緒言であ述べたように，本アルゴリズムの収束性を 支配する要因として，

(1) 係数行列の性質

（2）観測值データの選定法

(3) 扣速倞数

(4) 電力系統のサイズ

（5）計算モデルの精密化(三次項の導入)

が挙げられるが，実は(1)と(2)は密接に関係してい るので一緒に論ずることにし，更に本章では，(3)之 
(5)項について若干の検討を行なう。

\section{〈5・1〉 係数行列の性質と観測檤選定法との関係}

反復式(12) 加収束するための必要十分条件は〈3.1〉 節で述べたように係数行列 $A$ の正定值性之， $0 \leq \alpha \leq$ $\alpha_{m}<1$ なる加速保数の選択である。数学的に(14)式方 成り立つことは，必ずしも(12)式か数值に安定に収束 することを保証するものではないが，䍊測值セットの 選定法方行列 $A$ の性質にどう倸わってくるかを考察 しておくことは重要であるう。本節では線路潮流と電 圧值のみより成る観測值セット（以後 “LFV セット” と呼ふ）书よび注入電力，線路潮流，電圧值加らる 観測值セット(“ノーマルセット”之呼ぶ) を対象上し て検討する。

(1) IFV セット いま, $P L_{i j}, Q L_{i j}, V_{i}$ か 観測值セットの中に入っているとする。PLij，QLij は共化 $\boldsymbol{X}_{i}, \boldsymbol{X}_{j}$ のみの関数で

$$
\begin{aligned}
P L_{i j}= & V_{i} V_{j}\left(G_{i j} \cos \delta_{i j}+B_{i j} \sin \delta_{i j}\right) \\
& -G_{i j} V_{i}{ }^{2} \ldots \ldots \ldots \ldots \ldots \ldots \ldots \ldots \ldots \ldots \ldots \ldots \ldots \ldots \ldots \ldots \ldots \ldots \ldots \ldots \ldots \ldots \\
Q L_{i j}= & V_{i} V_{j}\left(G_{i j} \sin \delta_{i j}-B_{i j} \cos \delta_{i j}\right) \\
& +B_{i j} V_{i}{ }^{2} \ldots \ldots \ldots \ldots \ldots \ldots \ldots \ldots
\end{aligned}
$$

但し,$\dot{Y}_{i j}=G_{i j}+j B_{i j}$ は伝達アドミタンスである。 ここでは，Aの性質について概略の検討を行なうこと が目的なので, Hessian 行列の項 $B(x)$ を無視し， また $A=H^{T} R^{-1} A$ は k皇っって大きく変化しない ので, $P L_{i j}, Q L_{i j}$ のヤコビアンベクトルを直流法の 条件 $\delta_{i}=0, V_{i}=1(i=1 \sim N)$ で評価する。図了は， $\boldsymbol{X}_{i}, \boldsymbol{X}_{j}$ に対応するAの部分行列飞対する，上述の 3 観測值の需与を示したものである。同一観測地点にお ける PL とQL は同一の PT, CT, トランスシュー

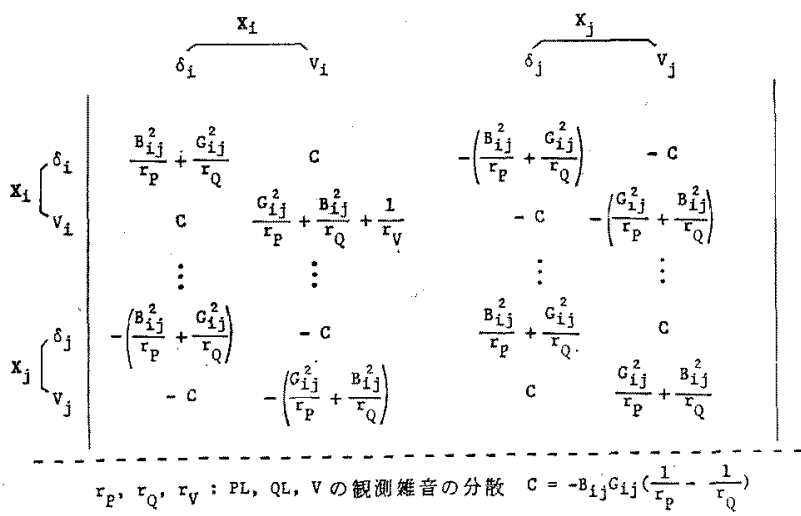

図3 線路潮流観測値の保数行列 $A$ への寄与

Fig. 3. The contribution of line flow measurement to the coefficient matrix $A$.
サから得るので, $r_{P} \simeq r_{Q}$ と仮定してよく $C \simeq 0$ とみ なすととができる。

従って，観测值セットが注入電力を含まないとき， $A$ は対称正定值で加 $a_{i j} \leq 0(i \neq j)$ となり, スティ ルチェス行列となる。このとき(10)式の分離に対し， $D^{-1} \geq 0 ，$ 加 $F \geq 0$ *峸り立ち，(10)式は正則分離 となる(12)。 $\alpha=0$ に対して，(13)式のヤコビ行列は $M_{0}=D^{-1} F=(A+F)^{-1}$ となり

$$
\rho\left(D^{-1} F\right)=\frac{\rho\left(A^{-1}\right) \cdot \rho(F)}{1+\rho\left(A^{-1}\right) \cdot \rho(F)}<1
$$

となることが証明できる(12)。

更に，Aについて次の二通りの正則分嵟を行なう。

$$
A=D_{1}-F_{1}=D_{2}-F_{2}
$$

$F_{2} \geq F_{1} \geq 0$ 汶対して，次式加成り立つ ${ }^{(12)}$ 。

$$
0<\rho\left(D_{1}^{-1} F_{1}\right)<\rho\left(D_{2}^{-1} F_{2}\right)<1
$$

上式は，Aがスティルチェス行列であるときはブロ ック分けを大きくした方が(12)式の収束がより早いて とを示している。しかし，本研究の対象である並列計 算アルゴリズムにおいては，分割を大きくす机ば所要 プロセッサの数は減少するが，逆にプロセッサ当りの 計算量が增加するので，全体として収束時間が早くな るかどうかは詳しく検討する必要がある。

（2）/ーマルセット $P_{i}, Q_{i}, V_{i}$ 办観測值に含 まれており，また説明の便宜上，ノード $i$ の隣接ノ一 ドは $j$ とのみとし，加 $j$ とを結占線路は存在し ないと仮定する。上述の観測値による $A$ への寄与(上 三角部分) を図 4 亿示す。非対角要装で波線を下に引 いた項は符号不定，甲とあるのは正，明示してない項 は負の要素である。点線で围んだ部分は注入電力観測 によって出現する項であり， $\delta_{j}-\delta_{k}, V_{j}-$ $V_{k}$ に対応する要素は共に正である。

かくて，注入電力を観測値として含むと き $A$ は単に正值対称行列上いう以上の性 䡠は得ら机ず，反復解法には余り好都合な 点はない。事実, 数值例の項で明らかにす るように，LFV セットに比較して収束ま での反復回数が相当多くなる。

$\langle 4.2\rangle$ 加速係数の選定 一般に，反 復解法の収束を早めるに法加速保数の導入 が有効であり，(12)式ばこのための式であ る。付録㐳示すように， $-1<\alpha<\alpha_{m}<1$ で ある限り(13)式のヤコビ行列 $M_{\alpha}$ は収束 行列となる。ガウスザイデル法では $\alpha_{m}=1$ であるが，十コビ法に揓いては $\alpha_{m}$ をきっ

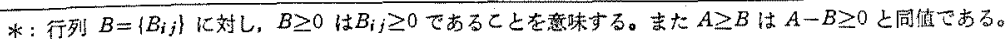

昭 $57-12$ 

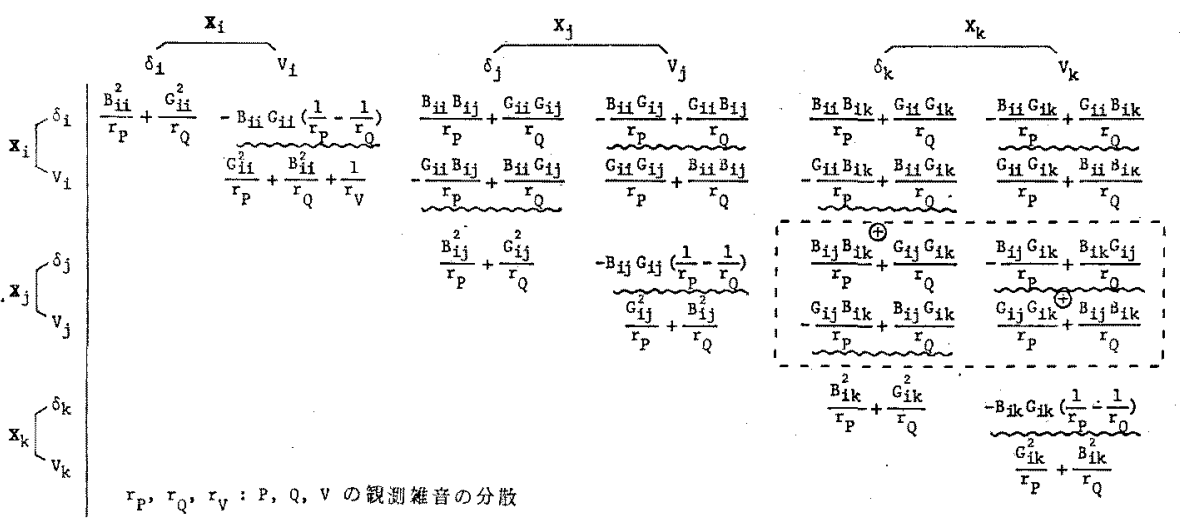

図 4 注入電力観測值の係数行列 $A$ への寄与

Fig. 4. The contricution of injected power measurement to the coefficient matrix $A$.

ちりと指定するてとができない。

\section{$\langle 4 \cdot 3\rangle$ 二次項導入による計算モデルの精密化}

ヤコビ法は $\hat{x}$ を得るまでの反復回数は N.R 法とは 比较にならぬほど多くなるので，二次項を導入するこ とによって計算モデルの精密化が可能かどうか検討す る価值がある。本研究では次の二方法を検討した。

方法 1……係数行列への Hessian 項の導入

静的状態推定問題哇重み付最小二重問題として定式 化されるので， $\hat{x}$ を求める式は(5)式上なり，之の倸 数行列 $\Gamma(x)$ には（6）式に示すように, Hessian 項が 入ってくる。通常，推定計算了ルゴリズムでは $B(\boldsymbol{x})$ を無視しているが，推定計算の最初の間は残差が大き いので収束の改善に役立つことが期待される。

方法 $2 \cdots \cdots$ 残差ベクトルの二次項の導入

第 $i$ 観測值に対応する $f_{i}(\boldsymbol{x})$ をテーラ展開の二次 項まで近似すると，先佂定義した $g_{i}(\boldsymbol{x}), G_{i}(\boldsymbol{x})$ を使い

$$
\begin{aligned}
f_{i}(\boldsymbol{x}+\Delta \boldsymbol{x}) \fallingdotseq & f_{i}(\boldsymbol{x})+\boldsymbol{g}_{i}(\boldsymbol{x}) \cdot \Delta \boldsymbol{x} \\
& \left.+\Delta \boldsymbol{x}^{T} G(\boldsymbol{x})\right) \cdot \Delta \boldsymbol{x}
\end{aligned}
$$

と表現できる。ここで，右辺第 3 項を $\lambda_{i}(\Delta x)$ とおき

$$
\Lambda(\Delta \boldsymbol{x})=\left(\lambda_{1}(\Delta \boldsymbol{x}), \cdots \cdots, \lambda_{m}(\Delta \boldsymbol{x})\right)^{T}
$$

之定義すると，(7)式をやや修正した形で次の二次項 を考虑した反復式が得られる。

$$
\begin{aligned}
& {\left[H\left(\boldsymbol{x}^{K}\right) R^{-1} H\left(\boldsymbol{x}^{K}\right)\right] \Delta \boldsymbol{x}^{K}} \\
& \quad=H^{T}\left(\boldsymbol{x}^{K}\right) R^{-1}\left(\boldsymbol{Z}_{M}-\boldsymbol{f}\left(\boldsymbol{x}^{K}\right)-\Lambda\left(\Delta \boldsymbol{x}^{K-1}\right)\right]
\end{aligned}
$$

この方法は，反復過程がかなり進んだ段階で反復式を 上の式の上うに変更することで，収束特性の良くなる ことを期待したすのである。

\section{6. 並列計算アルゴリズムのシミュレー ション結果}

第 3 章で提案した並列計算アルゴリズムの有效性を
検証するため，大形計算機によるシミュレーションを 行なった。IEEE 30，57，118 ノード采統を対象とし て取り上げ，各々の系統に第 5 章で述べた 2 種類の観 測值セットを選定した。一方は，線路潮流之電圧観椡 値のみより成る LFV セット，他方はほ活半数のノー ドの注入電力を観測值として含むノーマルセットであ り，乙の選定により注入電力観測値の影響を具体的に 検討することができる。また，観測值数は各系統とす 几長度が約 2 となるように選んだ。

〈3・2〉節で提案した並列アルゴリズムの適用に当っ $\tau$, 加速係数 $\alpha,(12)$ の式の最大反復回数 $l_{\max }$ およ $ひ ゙ \varepsilon_{l}, A$ の更新間隔, 収束基準 $\varepsilon_{K}$ などの諸パラメ 一タの決定が必要である。乙のため，初期のテストラ ンを多数回行なった結果，これらのパラメータは概略 次のように決定すればよいことが判明した。

(i) 加速係数 $\alpha$ は 0.6 0.7 が適切である。

(ii) $l_{\max }$ 法 $k$ の增加之共に, $40 \rightarrow 30 \rightarrow 20 \rightarrow 15 \rightarrow$ 10 之渐次減少させる。また， $\varepsilon_{l}$ あ $k$ の增加と共に $10^{-4} \rightarrow 10^{-5}$ となるように渐減させる。

（iii) $A$ の更新計算は $K_{\mathrm{up}}=4 \sim 6$ 回方適当である。

(iv) $k$ の小さい間は, $A$ の $\delta_{i}-V_{j}(i, j=1 \sim N)$ に対応する要素を雾とおく，つまり $A$ をデカップル して，。とV独立に解く方が収束が早い。

（v）収束判定基準は $\varepsilon_{K}=10^{-4}$ で十分である。

表 1 は上述の初期シミュレーションの結果選定した パラメータ值の基に, 各系統に対し並列計算アルゴリ ズムの適用結果をまとめたすのである。表中の総反復 回数注(12)式を解いた全回数を示しており, また推定 精度は次式で定義するあのを用いた。

$$
R_{\delta}{ }^{2}=\frac{1}{N} \sum_{i=1}^{N}\left(\hat{\delta}_{i}-\delta_{i t}\right)^{2}, \quad R_{V}=\frac{1}{N} \sum_{i=1}^{N}\left(\hat{V}_{i}-V_{i t}\right)^{2}
$$

但し， $\delta_{i z}, V_{i t}$ は真值を意味する。表中の推定並列計 
表 1 シミュレーション結果のまとめ

Table 1. The summary of the simulation results.

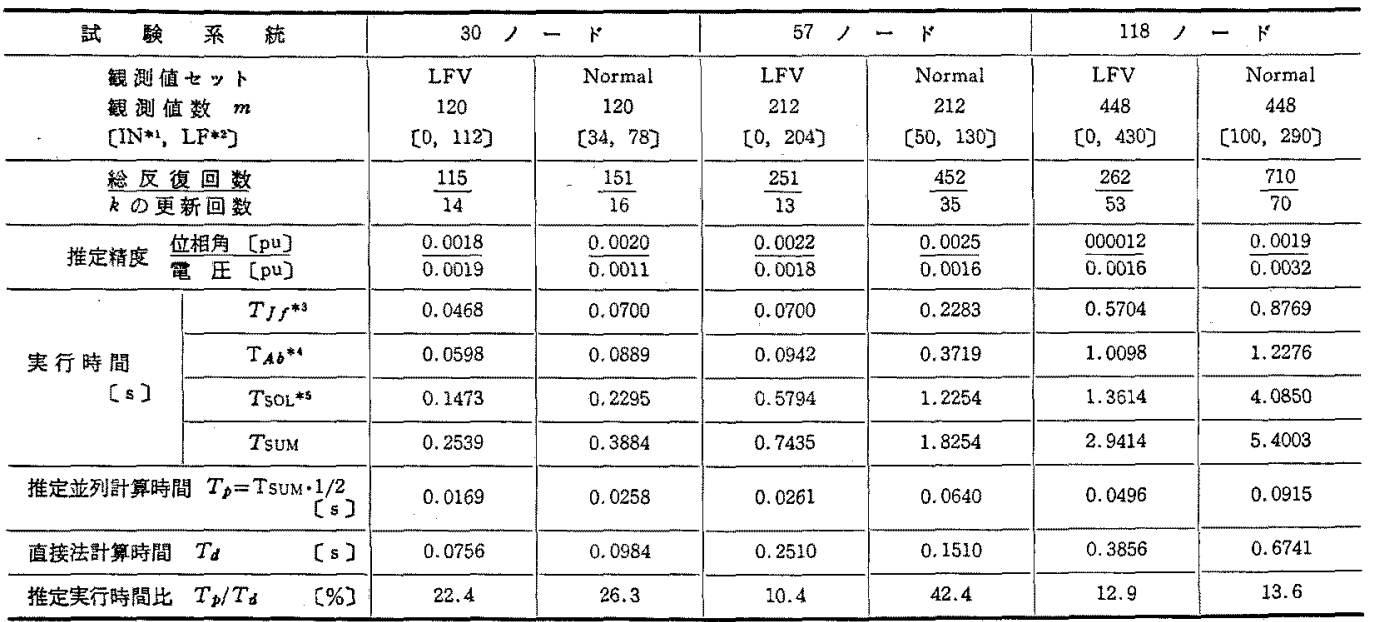

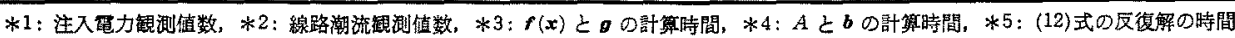

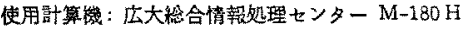

算時間 $T_{P}$ は

$$
T_{P}=T_{\text {SUM }}(K / N) K=2
$$

としているが， $K=2$ としたのは CPU のデータ伝送 やブロードカースティングによるオーバヘッドを見这 んだものである。以下に本表の結果について考察を加 えるとと汇する。

〈6.1〉 観測值セットの選定による影響 〈5.1〉節 で述べたように，LFV セットに対して係数行列は近 似的にスティルチェス行列とみなすととができるので 本諭文で提案するような反復解法にとって極わ的て好 都合であり，事実，総反復回数はつーマルセットに比 較してはるかに少ない。更に〈4・2〉節で述べだよう に，LFVセットに効しては $A$ 中の非雾要素数も少い ので計算は一層高速となる。

また，収束の精度加らるても，LFVセットの方が ノーマルセットより総じて良好であるてとがわかる。

従って，並列計算アルゴリズムに対しても文献(3) のように LFV セットが有効と考えら机る。

$\langle 6.2\rangle$ 加速係数の選定 加速係数の最適値を求 めるべく種々シミュレーションをしてみた。すちろん 最適值は系統により，また観測徝セットにより異なっ ているが，本研究で対象之した各ケースに共通な上限 值は $\alpha_{m}=0.7$ であった。 $\alpha=0.6$ としても総反復回数 は余り大きく違わないので，反復解法の数值的安定性 からみて $\alpha=0.6$ とした方がよいと思われる。

$\langle 6.3\rangle$ 並列計算による速度向上比直接法に上 って状態推定值を求的る計算は一般淿潮流計算よりも 時間がかかる。表 1 の最下行は並列解法による速度向
上此を示したすのであり，特に118ノード系に対して 住直接法の約 $13 \%$ 程度の時間で並列計算が実行でき ると推定される。

$\langle 6.4\rangle$ 二次項の導入の効果 表1加ら判る上う に，注入電力観測健を含むノーマルセットに対して は，系統のサイズに比例して総反復回数が增加してい る。このため，〈5・3〉節で提案した二次項余入の効果 を，特に57 ノード系について詳しく検討した。本章 の最初で述べたように，A 注最初デカップリングして 解いた方が収束が早いが，繰り返しがある程度進行し た段階では正確な $A$ を用いた方が解法式がより览密 になる。従って，ての点当含めて検討した。

表2 泳これらの比較結果をまとめたものでありケ 一ス 1 は基準状㦔(表 1 上同一)である。なお所要計算 時間はほぼ総反復回数に比例するので載せていない。

ケース 2 注 $K \geq 13$ 以降， $A$ を正確なすの纪戻して いるが，総反復回数は 25 回減少しており，乙の方法 の有効性がみられる。

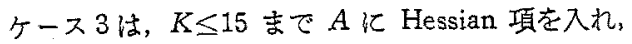
また $K \geq 13$ 以降上のケース同様に $A$ を正確にして いるが，殆んど Hessian 項導入の効果はみられな い。Hessian 項のみを導入すると, 総反復回数俚却っ て増加するが，てれは $A$ の正定值性が損われるのが 原因上考えられる。

ケース 4 注， $K \geq 4$ 以降右辺ベクトルに二次項を入 れ， $K \geq 13$ 以降 $A$ を同様に正確にしている。この組 合せが最も有効であり，総反復回数が 401 回へ減少し ている。 
表 2 二次項導入の䓵果

Table 2. The effect of intoduction of quadrature terms.

\begin{tabular}{|c|c|c|c|}
\hline & 方 & 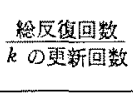 & $\begin{array}{l}\text { 推定精底 } \\
\text { 代相角 [pu] } \\
\text { 需 王 [pu] }\end{array}$ \\
\hline ケース 1 & 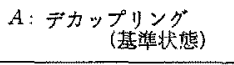 & $\frac{452}{35}$ & $\frac{0.0025}{0.0016}$ \\
\hline$ケ-\pi 2$ & $K \geq 13: A:$ 正磪 & $\frac{427}{34}$ & $\frac{0.0025}{0.0016}$ \\
\hline ケース 3 & $\begin{array}{l}K \geq 13: A: \text { 正確 } \\
K \leq 15: \text { 二次项 }(\text { 方法 } 1)\end{array}$ & $\frac{453}{44}$ & $\frac{0,0025}{0,0016}$ \\
\hline ケース 4 & 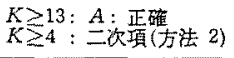 & $\frac{401}{30}$ & $\frac{0.0025}{0.0016}$ \\
\hline
\end{tabular}

\section{7. 結言}

本論文に书いては，オンライン適用を主目的とする 状龍推定計算の高速化の有力な方法として，マルチプ ロセッサシステムによる並列計算アルゴリズムの可能 性を検討した。対象とした解法は計算上の並列度の最 屯高いと考えら机る点ヤコビ法であり，状龍推定計算 に現われる正規方程式はその保数行列が正定值である ことから，対象とした系統に対してすべて推定計算は 収束した。更に，並列諎算法を高速に収束させるため には，線路潮流と電圧観測値のみを対象とすることが 望ましいことを理諭的に解明し，また数值例で立証し た。

本研究の成果は，将来のマルチプロセッサシステム に適した推定アルゴリズム開発の基本となるむのと期 待している。また, 近い将来状態推定計算専用のマル チプロセッサシステムが構成されるととになれば，真 に State Estimator と呼ぶふふむしいあのとなる。

末尾ながら，本研究の可能性について御示唆戴いた 早稲田大学岩本伸一助教授に感謝の意を表します。な 抢，計算は広島大学総合情報処理センターのM-180 を使用した。

(昭和 57 年 1 月 4 日受付，同 57 年 8 月 30 日再受付)

\section{文 献}

(1) E. Handschin: "Theoretical and practical considerations in the design of state estimators for electric power sys. tems", Computerized Operation of Power Systems, p. 104, Elesevier Publishing Company (1971)

(2) R.E. Larson: "State estimation in power systems, Part I \& II", IEEE Trans. Power Apparatus Syst. PAS-89, p. $345(1970)$

(3) J.F. Dopazo: "State calculation of power systems from line flow measurements", ibid, PAS-89, p. 1698 (1970)

(4) A. Garcia: "Fast decoupled state estimation and bad data processing", ibid, PAS-98, p. 1645 (1979)

(5) F.L. Alvarado: "Parallel solution of transient problems by trapezoidal integration", ibid, PAS-98, p. 1080 (1979)
(6) W. L. Hatcher: "A feasibility study for the solution of transient stability problems by multiprocessor structures", ibid, PAS-96, p. 1789 (1978)

(7) J. Fong: "Parallel Processing of Power system anlysis problems via simple parallel microcomputer sturctures". ibid, PAS-97, p. 1834 (1978)

(8) H.H. Happ: "Future computer technology for large power system simulation", Automatica, 15, p. 622 (1979)

（9）传々木: 「電力系統の犾热推定招ける亚列竍算アルゴリズム について」電気学会電力技術研究会 PE-81-38 (1981)

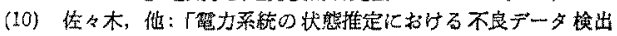
法」電学解 B 98,846 (昭 53-10)

(11) P.E. Gill \& W. Murray: "Algorithms for the solution of the nonlinear least-squares problem", SIAMJ. Numer. Anal. 15, No. 5 (Oct, 1978)

(12) R.S. Varga: Matrix Iterative Analysis, Prentice Hall Inc. (1962)

(13) J.K. Reid: Large Sparse Sets of Linear Equations, (1971) Academic Press

(14) 经々木：「電力系統の然態推定アルゴリズムの効率化に関す

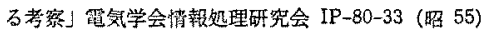

\section{付 録}

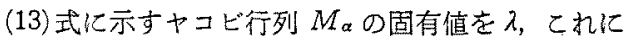
対応する固有ベクトルを $x$ とすると，

$$
\begin{array}{r}
{\left[-\alpha I+(1+\alpha) D^{-1} F\right] x=\lambda x} \\
\therefore(1+\alpha) A x=(1+\lambda) D x
\end{array}
$$

上式に $\boldsymbol{x}^{T}$ を左乗して

$$
(1+\alpha) \boldsymbol{x}^{T} \cdot A \boldsymbol{x}=(1-\lambda) \boldsymbol{x}^{T} D \boldsymbol{x}
$$

$A, D$ は共に正定值であるから， $\alpha>-1$ に対して

$\lambda<1$ (付 2)

上式は $A$ が正定值であれば必ず成り立つ。

一方， $M_{\alpha}$ を書き換えると，

$$
M_{\alpha}=-\alpha I+(1+\alpha)(I+G)^{-1} G
$$

ここで， $G=A^{-1} F_{0} G$ の固有值 $\tau$ に対応する固有心 クトルを $\boldsymbol{y}$ とすると，

$$
G \boldsymbol{y}=\tau \boldsymbol{y} \quad \therefore(I+G)^{-1} G \boldsymbol{y}=\tau /(1+\tau) \boldsymbol{y}
$$

この結果上り, 次式加得られる。

$$
\begin{aligned}
& M_{\alpha} \boldsymbol{y}=\lambda \boldsymbol{y}=\tau-\alpha / 1+\tau \cdot \boldsymbol{y} \\
& \therefore \lambda=\frac{\tau-\alpha}{1+\tau} \ldots \ldots \ldots \ldots . .
\end{aligned}
$$

即ち， $G$ の固有ベクトルは，また $M_{\alpha}$ の固有ベクト ルでああり，両者の固有值は(付 3)式で関係づけられ る。 $M_{\alpha}$ が収束行列であるための必要十分条件は $|\lambda|$ <1であり，(付 3 )式より $\lambda>-1$ なる条件を求める と

$$
\alpha<2 \tau+1
$$

一般に， $A$ が対称正定值よいうだけでは， $G=A^{-1} F$ の固有值の存在範囲は定まらない。従って， $M_{\alpha}$ が収 束行列であるための $\alpha$ の範囲は $-1<\alpha<\alpha_{m}<1$ とな るが， $\alpha \leq 0$ は減速係数となり䒠用上除外して，

$$
0<\alpha<\alpha_{m}<1
$$

